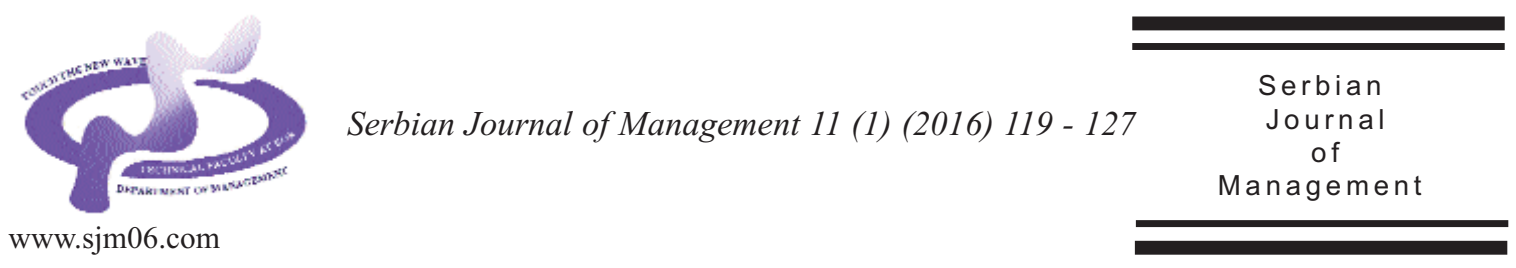

\title{
THE MANAGEMENT OF QUALITY COSTS ANALYSIS MODEL
}

\author{
Tomáš Holota ${ }^{a}$, Jozef Hrubec ${ }^{a}$, Martin Kotusa*, \\ Mária Holienčinováb and Eva Čapošovác
}
a Slovak University of Agriculture in Nitra, Faculty of Engineering, Department of Quality and Engineering Technologies, Tr. A. Hlinku 2, 94976 Nitra, Slovak Republic

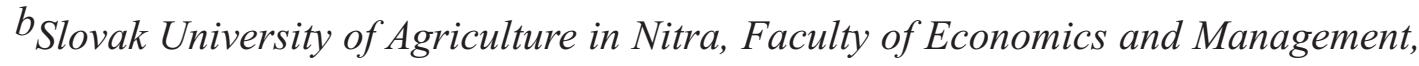 Department of Marketing, Tr. A. Hlinku 2, 94976 Nitra, Slovak Republic
${ }^{c}$ University of Ss. Cyril and Methodius in Trnava, Faculty of Social Sciences, Department of Public Administration, Nám. J. Herdu 2, 91701 Trnava, Slovak Republic

(Received 24 October 2015; accepted 1 December 2015)

\begin{abstract}
This article proposes a comprehensive introduction into the analysis and calculating costs and identifies the different areas of activities in company which can lead to improving the quality and reducing costs by using the PAF cost model. The basic precondition for quality improvement in company is understanding of the process and its control with regard to the objectives which should be achieved. PAF model is the most frequently used model for the quality costs analysis at present. In today's competitive environment, what all organizations consider as the first priority is to provide the customers with the highest quality for the best price. This can be achieved by setting optimal quality costs.
\end{abstract}

Keywords: PAF model, quality costs, analysis, efficiency, effectiveness, improving

\section{INTRODUCTION}

In implementing the quality management system it is needed to think of the consequences that the implementing system will cause. Therefore, measuring the effectiveness and efficiency of implemented system immediately after the introduction of quality management system belongs to the important activities. The aim of the quality management system is not only continuously improving a quality and fulfil customer requirements, but also find a way how to do it with the lowest costs. The lower costs can

\footnotetext{
* Corresponding author: martin.kotus@uniag.sk DOI:10.5937/sjm11-9347
} 
be achieved only by reducing cost of nonconformities correction that must be identified and measurable.

The basic precondition for quality improvement in the company is understanding of the process and its regulation with regard to the objectives that should be achieved. Processes must these objectives achieve efficiently, it means with the lowest internal costs and the largest value-added on the background of the process approach. Generally, with care about the quality, the cost of production quality assurance is not increasing but contrary is reduced significantly. Moreover, can be expected that increasing the quality will be for the customer so attractive that he will be willing to accept higher price of products. Measurement, analysis and evaluation of the quality costs is in implemented quality management system as important as measuring and analysing of the customer satisfaction. For the analysis and evaluation of the quality costs, there are many models that give a realistic picture about the efficiency and profitability of implemented system.

Process management is a systematic process of identification, visualization, measurement, evaluation and continuous process management as assurance that processes operate at the highest possible level of their potential, while there is a search for opportunities leading to their improvement and subsequent implementation of these opportunities into reality (Rolínek et al., 2014; Dado et al., 2012; Živković et al., 2009).

The main purpose of the article is to point out the possibilities of application PAF model (Prevention - Appraisal - Failure), which belongs among the most frequently applied models of the quality cost analysis.
Mentioned model was designed by Armand Vallin Feigenbaum in 1961. At that time, he served as President of the American Society for Quality.

\section{MATERIAL AND METHODS}

Costs related to the quality represent a specific economic category. If we want to build a functional quality management system in the organization, it is necessary to deal with the costs associated with ensuring and improving the quality of products, processes and systems. The basic effort is the reduction without jeopardizing the quality. Quality Management brought new ideas and practices in reducing costs in organizations for example via reducing machine downtime, reducing overproduction, optimizing transport, selection of appropriate manufacturing processes, etc. (Hrubec et al., 2009).

In the past, tendencies were on the basis of the main definition, to identify comprehensively as possible costs related to the quality. Thereby was created whole range of classification aspects, which more or less exhaustively, pointed to group of costs that need to be monitored in the selected area.

One of the first literatures related to the general term of quality costs is the book Quality Control Handbook by Dr. J. M. Juran. He suggested that quality costs can be understood from economic point of view on the final product quality, or from economics of conformity (Juran \& Godfrey, 1998).

Quality costs we could in the basic terminology defined as follows:

1. Quality costs are the sum of the cost of quality control and of all disagreements (Juran \& Godfrey, 1998). 
2. Quality costs are defined as the difference between price for conformity and price for non-conformity (Crosby, 1980).

3. Quality costs are interesting and specific economic categories (Čierna, 2006).

4. Quality costs are referred as controlled variables and resultant variables (Harrington, 2014).

\section{Economic analysis of quality}

Quality management in the company does not deal only with improving the quality, but also seeks to ensure the best business results by the quality. Therefore, the important part of quality management is the economic analysis of quality (Leščišin \& Macko, 2000).

Economic analysis of quality as an economic evaluation process of creating quality and its economic consequences subsumes two crucial aspects (Leščišin \& Macko, 2000):

- Firstly, must be evaluated economic benefits of quality for the customer, for whom, quality products and services should bring not only tangible benefits but also economic benefits.

- Secondly, should be evaluated economic benefits for the producer, who inserts into improving the quality tangible and intangible assets for the purpose of higher economic appreciation.

Linkages and impacts are the starting point for economic analysis of quality. All correlations are ultimately reflected in two synthetic categories - in prices for the quality and quality costs. Profit arises from their difference that is created in business entity through the quality (Leščišin \& Macko, 2000).

Armand Vallin Feigenbaum (1991) pointed out the relation between the prevention costs and reducing appraisal costs and reducing failure costs. This led to the creation of the PAF model (Prevention, Appraisal and failure). Model PAF represents prevention, evaluation, and internal and external failure, and also quality costs, from this follows the most definitions of quality costs.

The classification of PAF model consists from the following parts / steps (BS 6143-2, 1990).

\section{Prevention costs}

Prevention costs represent the operation costs which objective is identifying possible defects and disorders. It is important to avoid defects and disorders earlier than they will appear in product / service itself. Prevention costs should show sustained growth as the only one in the PAF model (seen in Figure 1). In the environment of organizations are considered for these costs for example training costs, costs for creation and development of quality management system, forecasting and planning quality costs and other (seen in Table 1).

\section{Appraisal costs}

Appraisal costs (also known under the term control costs) are costs that were incurred for the identification of nonconforming products / services, before they are delivered to the final customer. It includes all costs associated with activities which are performed during the manufacturing process to ensure required quality. The mentioned part can be in some companies very expensive. Among the appraisal costs we can include the cost of buying and calibration of measuring equipment, buying software that is used in the organization, and other (seen in Table 1).

3. Failure costs (internal and external)

Costs incurred for reprocessing or removing of defects from the product before 
delivery to the customer can be called "Failure internal costs". This group is composed of costs like: losses from irreparable nonconforming products, costs used for repair of nonconformities (not only in manufacturing process but also in the preproduction phases, service, etc.), losses from degradation of materials.

During delivery of nonconforming products to the customer incur external failure costs that belong to the least desirable ones considering to possible consequences for the organization. External failure costs arise due to failure of user requirements for quality after delivery to the customer. Apart from the typical items as indicated in Table 1 , in this group also belong discounts on the prices of products of substandard quality, loss of markets, the removal costs of defective products. Because these costs are always related with the loss of customer confidence, is their economic potential much larger than with the failure internal costs-there are known examples when costs to remove defect during mounting, are thousand times lower than costs for the elimination the same defect at customer.

The previous breakdown allows transparent monitoring of appreciation of preventive actions costs. And also allows the quality improvement against the quality decrease of other two points of classification in PAF model.

As can be seen in figure 1 , there is a graphic display of individual parts of PAF model classification with the total quality costs.

As can be seen in Figure 1, appraisal costs $\left(A_{c}\right)$ and failure costs $\left(F_{c}\right)$ are reducing by gradual increasing of quality level. In contrast, the prevention costs $\left(\mathrm{P}_{\mathrm{c}}\right)$ are growing by improving the quality. Total overview of the costs with the increasing quality represents the curve of total quality costs $\left(\mathrm{TQ}_{\mathrm{c}}\right)$, which is the result of solving an equation where each variable represents the value of money in a given currency (Feigenbaum, 1991):

$$
T Q_{c}=P_{c}+A_{c}+F_{c}
$$

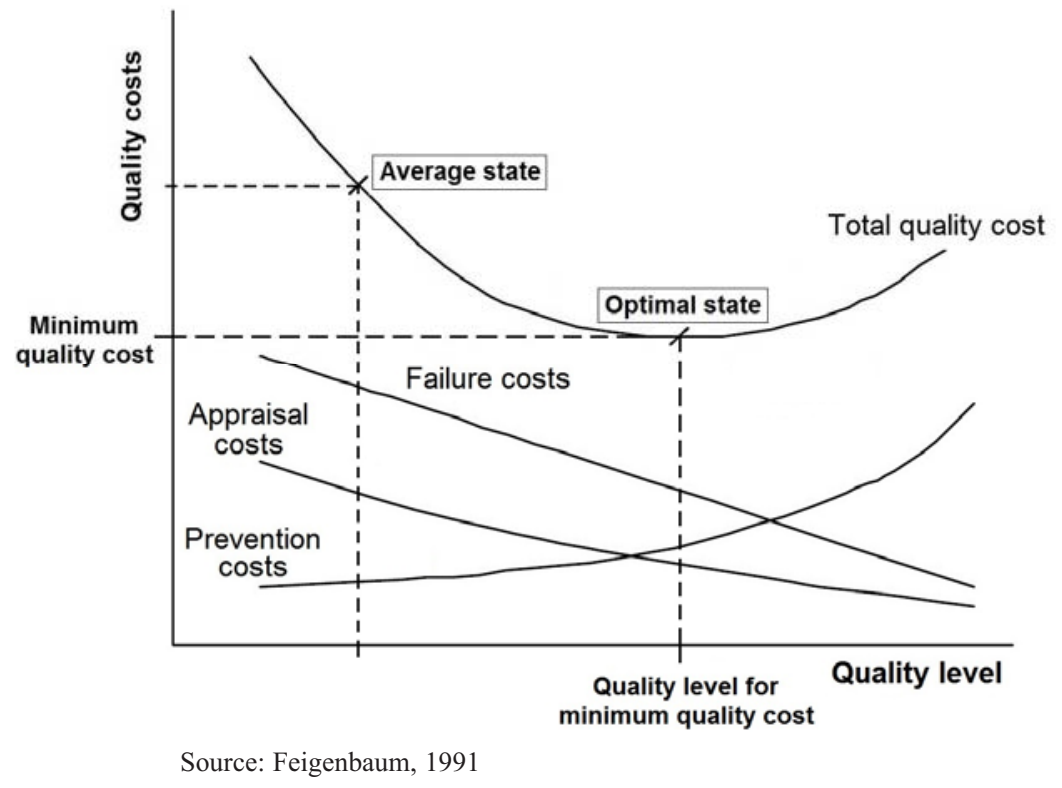

Figure 1. Graphical display of quality costs according to the PAF model 
In the Figure 1, the optimum state of total quality costs shows the top of parabola. This point represents the point where meet the optimal prevention costs, the appraisal costs and the internal and external failure costs in achieving a higher quality level.

A more detailed overview of individual parts of the classification PAF model, with examples to individual parts, is plotted in the following Table 1.

Application procedure of PAF model:

\section{Team creating}

It is necessary to pay a great attention to the selection of individual members. The members should thoroughly know the organization and be qualified in the area, which will be assigned to the analysis. These teams should have the full support from top management, to be able to prepare a cost model of process.

\section{Identification of process}

The selected process must be identified, isolated and named as a discrete set of activities. Owner of process must also be identified and informed. The outputs of the process must be identified according to how they go to the customer, it follows that the customer is the owner of the next process. The inputs to the process should be defined (e.g., material, employees, information, etc.). Control elements of the process and resources must be identified.

Table 1. Detailed classification of PAF model with examples of costs

\section{PAF model}

\begin{tabular}{|c|c|c|c|}
\hline $\begin{array}{l}\text { Area of } \\
\text { costs }\end{array}$ & & Description & Examples \\
\hline \multirow[t]{2}{*}{$\begin{array}{l}\text { Control } \\
\text { costs }\end{array}$} & $\begin{array}{l}\text { Prevention } \\
\text { costs }\end{array}$ & $\begin{array}{l}\text { Costs required } \\
\text { to avoiding the } \\
\text { occurrence of } \\
\text { nonconformities. }\end{array}$ & $\begin{array}{l}\text { Organizational and managerial costs for quality management } \\
\text { system } \\
\text { Educational and motivational costs for employee } \\
\text { Cost of external advisory and consultancy organizations } \\
\text { Cost of information technology and programs } \\
\text { Cost of design and product / service development } \\
\text { Cost of continuous process improvement } \\
\text { Cost of new manufacturing machine purchase } \\
\text { Cost of marketing research } \\
\text { Cost of monitoring customer satisfaction }\end{array}$ \\
\hline & $\begin{array}{l}\text { Appraisa } \\
\text { costs }\end{array}$ & $\begin{array}{l}\text { Costs for } \\
\text { control } \\
\text { mechanisms } \\
\text { and } \\
\text { nonconformitie } \\
\text { s detection. }\end{array}$ & $\begin{array}{l}\text { Cost of internal and external conformity control for purchased } \\
\text { materials } \\
\text { Cost of documentation control to the processes } \\
\text { Cost of purchase and maintenance for controlling equipment } \\
\text { Cost of work control } \\
\text { Cost of quality audits and other controlling audits } \\
\text { Cost of field testing }\end{array}$ \\
\hline \multirow[t]{2}{*}{$\begin{array}{l}\text { Failure } \\
\text { control } \\
\text { costs }\end{array}$} & $\begin{array}{l}\text { Interna } \\
\text { failure } \\
\text { costs }\end{array}$ & $\begin{array}{l}\text { Costs incurred } \\
\text { in removing of } \\
\text { identified } \\
\text { nonconformities } \\
\text { in the } \\
\text { organization. }\end{array}$ & $\begin{array}{l}\text { Cost of uncorrectable nonconformities (scrap) } \\
\text { Costs associated with the repair of nonconformities, respectively } \\
\text { reworking } \\
\text { Costs from delivered nonconforming materials } \\
\text { Costs associated with the difference of registered and actual } \\
\text { volume material in stock } \\
\text { Costs associated with corrective actions }\end{array}$ \\
\hline & $\begin{array}{l}\text { External } \\
\text { failure } \\
\text { costs }\end{array}$ & $\begin{array}{l}\text { Costs incurred } \\
\text { after delivery of } \\
\text { the product at } \\
\text { customer. }\end{array}$ & $\begin{array}{l}\text { Costs associated with the claim in the guarantee } \\
\text { Cost of storage and expedition for spare parts } \\
\text { Costs for penalties of failure to comply agreed conditions } \\
\text { Cost of product responsibility } \\
\text { Costs for the lost legal proceedings and overall reduced } \\
\text { organization image }\end{array}$ \\
\hline
\end{tabular}




\section{Identification of costs}

Each process contains the several key actions that must be identified. Next are determined and identified cost of conformity and non-conformity for each activity in the process.

\section{Cost report}

The organization must choose a uniform format of cost report. Report must contain a complete cost list of conformities and nonconformities of individual activities and next: identification of all inputs and outputs, control elements and process resources, determination of fixed costs (their value is not directly depended on production volume) and variable costs (their value is increased with production volume), calculation method for each element cost and collected data source.

\section{Process improvement}

Activities to improving effectiveness and efficiency of the process should be planned on the basis of information contained in this report and intended as a priority. Process owner should set an iterative cycle of individuals in the process and monitor changes in costs. After performed change to improving operation in the first activity of process, subsequently are performed changes according to the importance of individual action process. The result should be an overall economic and qualitative balance with a positive effect on the process.

6. Informing the management

After project completion with the application of PAF model for the selected process, is important to inform top management about the final economic and qualitative results. Establish recommendations for the future, which would lead to the next application of PAF model into the other running processes in the selected organization.

\section{RESULTS}

Organization didnàt use any model for improving effectiveness and efficiency before implementing PAF model. As it is shown in the Table 2, to individual activities in the organization were determined percentage shares on the total cost. The three largest share of the cost belonged to the categories Failure and Appraisal, together $86 \%$. After application of PAF model the largest share of costs focuses on prevention i.e. $45 \%$. We also recorded an overall decrease of costs about $37 \%$. Condition of prevention costs, appraisal costs and failure costs before the change and after the change is shown in Figure 2.

Table 2. Example of costs for various activities with percentage share in the MibaSteeltec Ltd.

\begin{tabular}{|c|c|c|c|}
\hline $\begin{array}{l}\text { Actions } \\
\text { (Activities) } \\
\text { in organization }\end{array}$ & $\begin{array}{l}\text { Cost of } \\
\text { quality } \\
\text { category }\end{array}$ & $\begin{array}{l}\text { Percentage } \\
\text { share } \\
\text { before } \\
\text { change } \\
\end{array}$ & $\begin{array}{l}\text { Percentage } \\
\text { share after } \\
\text { change }\end{array}$ \\
\hline $\begin{array}{l}\text { Change } \\
\text { Management }\end{array}$ & Prevention & $2 \%$ & $14 \%$ \\
\hline $\begin{array}{l}\text { Internal Quality } \\
\text { Issues }\end{array}$ & Failure & $28 \%$ & $4 \%$ \\
\hline $\begin{array}{l}\text { External } \\
\text { Quality Issues }\end{array}$ & Failure & $21 \%$ & $2 \%$ \\
\hline $\begin{array}{l}\text { New Product } \\
\text { Introduction } \\
\text { (NPI) Support }\end{array}$ & Prevention & $6 \%$ & $6 \%$ \\
\hline $\begin{array}{l}\text { Project Life } \\
\text { Cycle of } \\
\text { Deliverables }\end{array}$ & Appraisal & $21 \%$ & $5 \%$ \\
\hline $\begin{array}{l}\text { Lean } \\
\text { Manufacturing } \\
\text { Tools }\end{array}$ & Prevention & $5 \%$ & $17 \%$ \\
\hline $\begin{array}{l}\text { Quality } \\
\text { Reporting }\end{array}$ & Appraisal & $16 \%$ & $7 \%$ \\
\hline \multirow{2}{*}{$\begin{array}{l}\text { Continuous } \\
\text { Process } \\
\text { Improvement }\end{array}$} & Prevention & $1 \%$ & $8 \%$ \\
\hline & $\begin{array}{l}\text { Total } \\
\text { Reduction }\end{array}$ & $100 \%$ & $\begin{array}{l}63 \% \\
\% \\
\end{array}$ \\
\hline
\end{tabular}

Source: Own work 


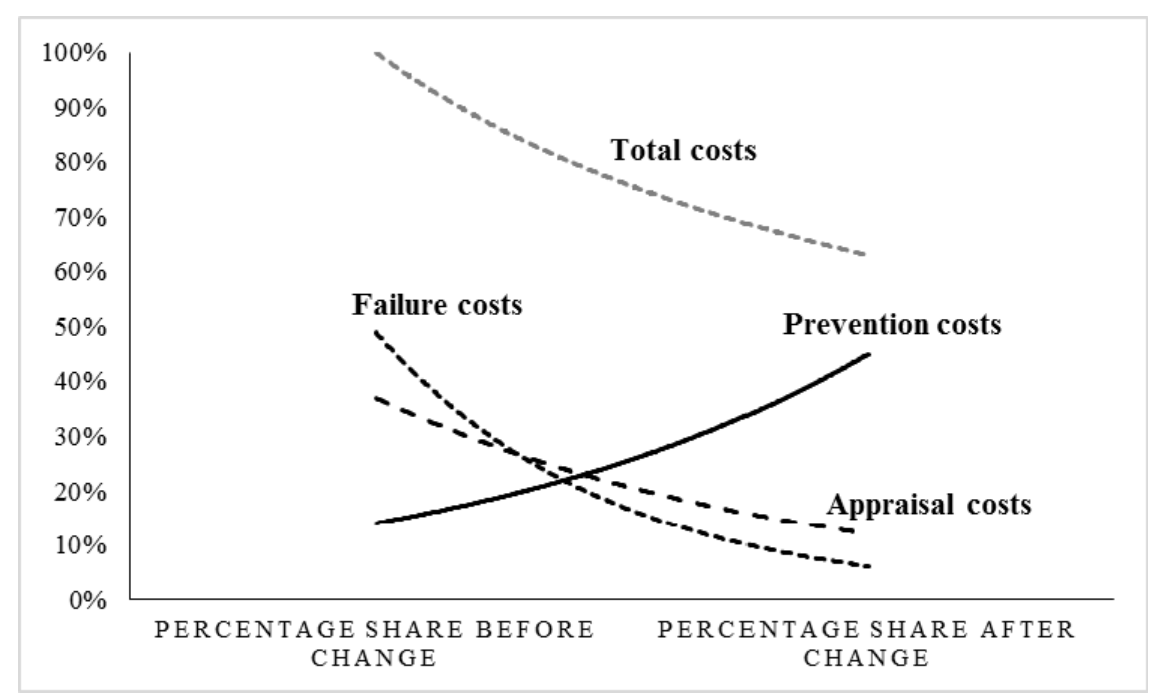

Source: Own work

Figure 2. Graphical display of quality costs in the MibaSteeltec Ltd.

\section{CONCLUSION}

For most provided examples of quality costs in Table 1 apply as follows that it is possible to eliminate them by using effective and efficient quality management system and in many cases completely to remove. Therefore, the organization should do a systematic and comprehensive financial analysis of various processes and departments in the organization, despite of the fact that prevention costs belong to the group of permanently increasing costs related to the quality. However, the recommendation for their sustained growth is still followed by a reduction of all unproductive expenditure in the company.

Customers require products (Novotnz̧, 2015) with characteristics which comply with their needs and expectations, which are expressed in product specifications and are referred to as customer requirements. The customer can specify own requirements in the contract or may be determined by the organization itself. In both cases, the customer determines the acceptability of the product (Mura \& Novotný, 2014; Matisková, 2013; Mura \& Buleca, 2012).

Long-term experience shows that only those businesses can succeed in the current supercompetitive environment which constantly improve their products and services and actively improve their business and production processes (Hajdu et al., 2014; Matisková, 2013).

Analysis of customer requirements / market expectations are currently undervalued in many organizations, on the other hand, customers are more demanding to their requests on the product. It can be concluded that customer satisfaction on the market at present is an indicator of creating greater economic benefits for the organization.

Application of PAF model is not complicated for realization, in context of existence similar running activities in organizations.

Moreover, replication of this study in other national and cultural contexts would be valuable (Nikić et al., 2014; Andreev \& Panayotova, 2013). 
By applying PAF model in organization MIBA Steeltec Ltd. was achieved increasing the effectiveness and efficiency of quality management system and improved economics results. Economic analysis results were performed by using basic management practices i.e. Analysis of inputs and outputs.

Finally, it is important to emphasize its principal benefit in terms of improving the overall quality and economic financial results.

\section{References}

Andreev, O.D., \& Panayotova, T.P. (2013). Customer Order Decoupling Point Issues in a Project Environment. Serbian Journal of Management, 8 (2), 243-254.

BS 6143-2:1990. Guide to the economics of quality: Prevention, appraisal and failure model.

Crosby, P.B. (1980). Quality Is Free: The Art of Making Quality Certain. Mentor Books, Dublin.

Čierna, H. (2006). Economics of quality. Faculty of Economics MBU in Banskõ Bystrica. (in Slovak)

Dado, J., Taborecka Petrovicova, J., Cuzovic, S., \& Rajic, T. (2012). An Empirical Examination of the Relationships between Service Quality, Satisfaction and Behavioral Intentions in Higher Eduction Setting. Serbian Journal of Management, 7 (2), 203-218.

Feigenbaum, A.V. (1991). Total Quality Control. third ed., McGraw-Hill, New York.

Hajdu, Z., Andrejkovi ， M., \& Mura, L. (2014). Utilizing experiments designed results during error identification and improvement of business processes. Acta Polytechnica Hungarica, 11 (2), 149-166.

Harrington, J.H. (2014). Maximizing Value Propositions to Increase Project
Success Rates. first ed., Taylor \& Francis Inc, Oxford.

Hrubec, J., et al. (2009). Integrated Management System. SUA in Nitra. (in Slovak)

Juran, J.M., \& Godfrey, A.B. (1998). Juranàs quality handbook. fifth ed., McGraw-Hill Companies, Inc., New York.

Leščišin, M., \& Macko, J. (2000). Quality management. Ekonúm, Bratislava. (in Slovak)

Matisková, D. (2013a). Strategic planning - the basic of quality in enterprise management. Kvalita, 21 (1), 37-40. (in Slovak)

Matisková, D. (2013b). Requirements for quality management systems in manufacturing companies. Posterus.sk, 6 (7), 1-7. (in Slovak)

Mura, L., \& Novotnz̧, J. (2014). Chapters from the small and medium businesses. Komárno. (in Slovak)

Mura, L., \& Buleca, J. (2012). Evaluation of Financing Possibilities of Small and Medium Industrial Enterprises. Procedia Economics and Finance, 3, 217-222.

Nenadal, J. (2002). Modern quality management systems. second ed., Management Press, Praha. (in Czech)

Nikić, G., Travica, V., \& Mitrovi , M. (2014). Defferences Between Employees and Managers Regarding Socio-Emotional Competences. Serbian Journal of Management, 9 (2), 281-292.

Novotný, J. (2015). Instrumentation CRM on the gaming technology market. Ostrava: KEY Publishing. (in Czech)

Rolínek, L., Vrchota, J., Kubecová, J., \& Švárová, M. (2014). The Level of Process Management Principles Application in SMEs in the Selected Region of the Czech Republic. Serbian Journal of Management, 9 (2), 203-217. 
УПРАВЉАЊЕ МОДЕЛОМ АНАЛИЗЕ ТРОШКОВА КВАЛИТЕТА

Tomáš Holota, Jozef Hrubec, Martin Kotus, Mária Holienčinová, Eva Čapošová

\section{Извод}

Овај рад представља свеобухватан увод у анализу и прорачун трошкова и идентификује различите области активности у компанији које могу довести до побољшања квалитета и смањења трошкова применом "РАF" модела трошкова. Основни предуслов за побољшање квалитета у компанији је разумевање процеса и његова контрола у вези са циљевима које треба постићи. "РAF" модел је тренутно најчешће коришћен модел за анализу трошкова квалитета. У данашњем конкурентском окружењу, све организације као приоритет сматрају пружање највишег квалитета клијентима, за најбољу могућу цену. То се може постићи формирањем оптималних трошкова квалитета.

Кључне речи: PAF модел, трошкови квалитета, анализа, ефикасност, ефективност, побољшање

Wood, D.C. (2013). Financial Measures for Strategic Implementation of Quality Management. fourth ed., American Society for Quality Press, Milwaukee.

Živković, Ž., Mihajlović, I., \& Prvulović, S (2009). Developing Motivation Model as a Strategy for HRM in Small Enterprises under Transitional Economy. Serbian Journal of Management, 4 (1), 1-27. 